\title{
Osman Lins na televisão
}

\author{
Ermelinda Maria Araújo Ferreira"
}

Adriano Siqueira Ramalho Portela**

\section{Resumo}

O escritor pernambucano Osman Lins (1924-1978), romancista, contista e dramaturgo, foi um acirrado defensor da palavra e um crítico ferrenho da indústria cultural. Nos anos 1970, entretanto, a convite da Rede Globo, produziu três roteiros para o programa "Caso Especial", que foram adaptados e exibidos no horário nobre da emissora. Infelizmente, esse foi um de seus últimos trabalhos, tendo o autor falecido vítima de um câncer, deixando para trás vários projetos inacabados, como o romance $A$ cabeça levada em triunfo e o seu ingresso - como "sabotador", segundo ele - no mercado do entretenimento "massificado" que crescia vertiginosamente no Brasil da ditadura militar. Neste artigo, comentamos sobre a incursão do autor no gênero policial, a partir da análise de um de seus textos escritos para a televisão: "Uma ilha no espaço", publicado em 1978 pela Editora Summus.

Palavras-chave: Osman Lins. Casos Especiais da Rede Globo. Indústria Cultural. Uma ilha no espaço.

\section{Osman Lins e a indústria cultural}

Referindo-me às sugestões no sentido de o escritor utilizar meios da indústria cultural, declarei: poderá um romancis-

ta, um poeta, ocasionalmente, levar-lhes contribuições: não, porém, a eles aderir, abandonando o livro.

Osman Lins

\footnotetext{
Professora doutora do Programa de Pós-Graduação em Letras da Universidade Federal de Pernambuco, líder do Núcleo de Estudos em Literatura e Intersemiose (Neli/CNPq), colaboradora do Instituto de Estudos Modernistas da Universidade Nova de Lisboa. Autora, entre outros, de Cabeças compostas, a personagem feminina na narrativa de Osman Lins (São Paulo: Edusp, 2005) e organizadora, entre outros, de Vitral ao sol: ensaios sobre a obra de Osman Lins (Recife: Edusp, 2004), e Osman Lins 85 anos: a harmonia de imponderáveis (Recife: Edusp, 2007). E-mail: ermelindaferreir@uol. com.br

* Formado em Jornalismo, Cineasta, Mestre em Teoria da Literatura pela Universidade Federal de Pernambuco com a dissertação "Escritas em Movimento: os "Casos especiais" de Osman Lins para a televisão", defendida em 2017. E-mail: reporterportela@gmail.com
} 
É ponto pacífico entre os críticos que o escritor Osman Lins foi um arquiteto da palavra: sabia que o ato de escrever é fruto de um trabalho insistente para atingir a perfeição. Em seu livro Guerra sem testemunhas (1969), ele afirmou que só escrevendo era capaz de aferir conceitos, revisar valores, pesar o imponderável, desfiar o tecido das ideias e avançar na obscuridade das coisas. Entretanto, a crítica também concorda que o autor era um "homem do seu tempo": um intelectual atuante e engajado nas questões prementes de sua história e de seu país, responsável por uma produção criativa e ensaística que não deixa dúvidas sobre a sua inserção na realidade.

A epígrafe é explícita: a lealdade do escritor é para com o seu meio, com o livro. Isso não significa, porém, que não possa incursionar noutras áreas, explorar outras possibilidades e conhecer outras formas de dizer. Sua ligação com as artes plásticas, com o teatro e com a música, por exemplo, já foram apontadas em inúmeros trabalhos acadêmicos. Seu vínculo com o cinema foi documentado em estudos sobre as influências do nouveau roman e da nouvelle vague nos seus experimentalismos narrativos. Existem estudos que abordam o caráter protohipertextual de sua escrita fragmentária, estruturada como um jogo; e até um site que transforma o romance Avalovara num produto multimídia e interativo na internet, mostrando como a sua linguagem antecipava o funcionamento do texto digital da era do computador doméstico.

Entretanto, a sua breve passagem pela indústria cultural e pelos mass media parece ter sido esquecida, restando um silêncio sobre essa aventura que seria a derradeira em sua breve existência, tendo o escritor falecido aos 54 anos, em consequência de um câncer, deixando para trás vários projetos inacabados, como o romance A cabeça levada em triunfo, e o seu incipiente - e surpreendente - trabalho como roteirista de televisão.

Nascido em Vitória de Santo Antão, Pernambuco, Osman Lins é autor de contos, romances, narrativas, ensaios e peças de teatro. O romance Avalovara (1973) é considerado sua obra-prima. O livro intercala oito narrativas que permeiam tempos e espaços distintos, tendo como ponto de partida o modelo gráfico de uma espiral e um quadrado e é um exemplo acabado do impulso artístico experimentalista desse autor. As influências das artes plásticas e da música nesta obra já foram muito documentadas. Também há estudos sobre a presença da oralidade em seu último romance publicado, A rainha dos cárceres da Grécia (1976), jogo de encaixes abissais onde uma personagem é descrita como "locutora de rádio".

Entretanto, a presença da mídia tecnológica na ambientação de suas narrativas é rara. Ouvimos o som de uma vitrola tocando em disco de vinil a ópera Catulli Carmina, de Carl Orff, na sala de um apartamento em São Paulo, disputando 
com o ruído do tráfego e das britadeiras a audiência da música de Avalovara. Ainda nesse romance, vemos os protagonistas de um dos capítulos, pegos de surpresa no café de uma praça em frente à Catedral Notre-Dame de Paris, tentando escutar a orquestra e o coro de uma apresentação do salmo In convertendo dominus, de Campra, "triturados pelo barulho dos veículos", sobretudo dos canos de escape das motocicletas. A tecnologia está presente, assim, como "invasora" do silêncio, do encontro, do diálogo e da meditação próprios da literatura. É quase sempre uma rival da escrita, e do trabalho árduo, lento e recompensador da criação artística.

Por outro lado, a indústria cultural sempre rondou o escritor e sua obra. Antes da produção das narrativas adaptadas, a TV Cultura produziu e exibiu uma telenovela baseada no premiado romance $O$ fiel e a pedra (1961), de sua autoria, levada ao ar de agosto a setembro de 1981, às 21h, com adaptação de Jorge Andrade e direção de Edison Braga. Desse trabalho só restaram, arquivados no centro de documentação da emissora, alguns capítulos esparsos dentre os 30 originais. Mais recentemente, porém, assistimos à bem-sucedida investida do diretor Guel Arraes, que transformou uma peça teatral de Osman Lins, a comédia Lisbela e o prisioneiro (2003), numa minissérie exibida pela Rede Globo em 1994. Posteriormente, em 2003, o texto foi adaptado pelo mesmo diretor para o cinema, transformando-se num filme de grande bilheteria, com atores conhecidos do grande público, o que incentivou à reedição da peça, bem como o recrudescimento do interesse dos leitores pela obra do pernambucano.

Infelizmente, essa publicidade parece ser esporádica e momentânea, retornando a obra ao reduto fechado dos estudos acadêmicos, e da admiração dos críticos e leitores mais especializados. A relação de Osman Lins com as massas não parece destinada a uma grande intimidade; embora essa, talvez, não fosse a vontade do autor. Apesar de ter dedicado sua vida ao trabalho burocrático no Banco do Brasil - o que consumiu grande parte do tempo que desejaria ter dedicado à sua obra -, não são raras as vezes em que ele se manifesta com indignação sobre a inexistência de financiamentos específicos na área cultural para a produção literária no país. Seu entendimento é que a produção de textos criativos é um trabalho, uma atividade como outra, e como tal deveria ser encampada, apoiada, valorizada e reconhecida. Para espanto geral, costumava identificar-se como "escritor" sempre que indagado sobre sua profissão.

Não surpreende, pois, que, ao constatar o vertiginoso avanço dos meios de comunicação na sociedade da segunda metade do século XX, com a penetração da "caixa de imagens", substituindo rapidamente a "caixa dos sons" na decoração das salas e na intimidade das famílias brasileiras, Osman Lins tenha vislumbrado no veículo uma enorme potencialidade para a educação e para a inserção de conteúdos num país de tão vasta extensão, com tão grande carência 
de escolas, mestres e bibliotecas, e tão alarmantes índices de analfabetismo preocupação que não cessou de denunciar em seus artigos jornalísticos. $\mathrm{Na}$ introdução à edição de seus roteiros, ele afirmou que a chance de escrever para um veículo de massa representava até mesmo uma pausa no "angustiante isolamento" que padecia enquanto escritor:

O criador da literatura não se define, unicamente, por uma certa maneira de dizer; e sim, também, por uma certa maneira de ver. Inserido no mundo, ele pensa a sua condição e a dos seus semelhantes. Num país como o nosso, o escritor que lida com um material de fruição mais difícil, e, para muitos, inacessível, sofre na carne uma espécie de segregação. Há um abismo quase infranqueável entre ele e a imensa maioria do povo. Então, uma tentativa como esta, significa uma pausa em nosso angustiante isolamento. Uma realização que é, ao menos, mais sincera e mais honesta, vence a massa de produtos realizados com fins comerciais e sem qualquer respeito pelo público. E é possível que não só algumas preocupações temáticas do autor, mas também algo do seu envolvimento com as palavras, alcancem os espectadores. Os quais, em sua maioria, não havendo chegado ao estágio de leitores, nunca tiveram e dificilmente terão nas mãos uma obra literária (LINS, 1978, p. 8).

Mas também é possível que o autor tenha vislumbrado, no rápido avanço das tecnologias da informação midiática, a abertura de uma oportunidade concreta para a sua tão almejada profissionalização, com a sua inserção num meio onde pudesse propagar suas ideias e suas histórias, multiplicando sua ação no mundo para muito além do que o veículo do livro impresso lhe permitiria alcançar, no contexto cultural de seu país e de sua época.
Figura 1

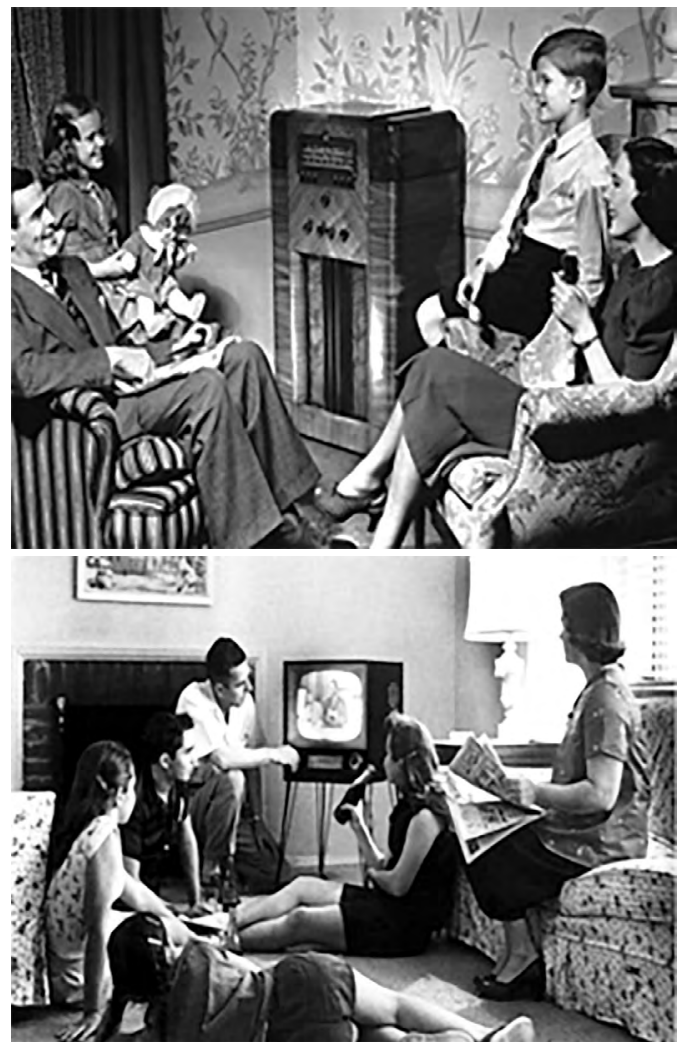

Fonte: banco de imagens do Google

O lazer das famílias no alvorecer do século $\mathrm{XX}$ : as caixas tecnológicas de transmissão invadem as salas de estar, estabelecendo novos comportamentos e modificando a percepção dos indivíduos.

Inaugurada em 18 de setembro de 1950, por Assis Chateaubriand, fundador do primeiro canal do Brasil, a TV Tupi de São Paulo, a televisão cresceu no país como um símbolo de avanço e modernização - anunciada, mesmo, como "A máquina de ir à lua", numa referência à transmissão mundial do dia 20 de julho de 1969 da viagem da Apolo 11, divulgada como a maior conquista técnica e científica da história da humanidade, que contou 
com mais de 500 milhões de espectadores assistindo "ao vivo" ao acontecimento. Maior audiência conseguida até então em escala mundial, a televisão foi o ingrediente fundamental do primeiro marco verdadeiramente planetário de conquista do "espaço midiático", talvez mais do que do "espaço sideral". ${ }^{1}$

Uma rede de vinte estações terrestres interconectadas com satélites sobre o Atlântico, o Pacífico e o Índico, permitiram levar o sinal gerado pela Nasa aos telespectadores dos Estados Unidos, América Latina, Europa, Norte da África, Ásia e Austrália. O distante Alasca recebeu a cobertura por meio de um satélite da força aérea e de uma antena do exército. A televisão se posicionou, assim, como um meio ideal, em plena Guerra Fria, de formação da "opinião pública”. Os Estados Unidos, que disputavam com a União Soviética a liderança na Terra e, quiçá, fora dela, devem muito de sua hegemonia ao domínio da informação massiva. As empresas produtoras e revendedoras do aparelho transmissor também absorveram a mensagem da conquista desse novo e fundamental "espaço" de mobilização das "massas". A verdadeira "viagem", assim, não foi tanto a do foguete para a Lua, mas a do aparelho de televisão para o interior das mentes e das percepções humanas em escala mundial. As propagandas da Telefunken e da General Eletric adquirem, assim, conotações divinatórias, proclamando a todos, ironicamente, a verdade a respeito das viagens espaciais tão em voga nos anos 1960.

Figura 2
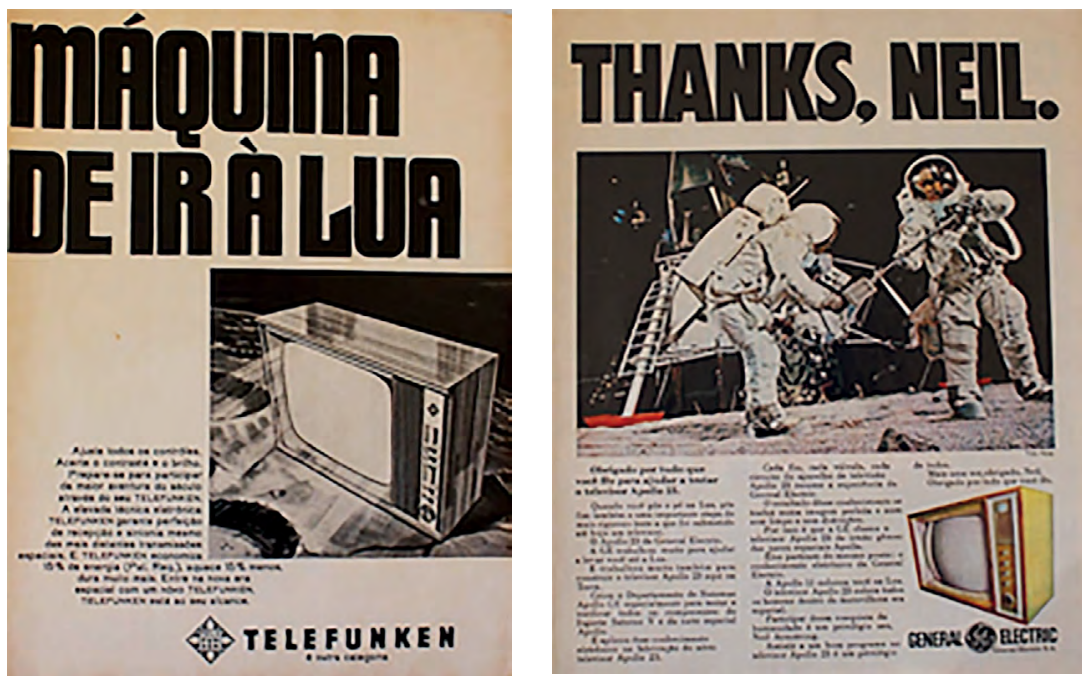

Fonte: banco de imagens do Google.

Propagandas da Telefunken e da General Eletric, afirmando que "o televisor Apollo 23, irmão gêmeo das naves espaciais Apollo, trabalhou muito para ajudar a levar você até a Lua: obrigado, Neil, por tudo que você fez". 
O avanço da televisão no Brasil ocorreu durante os chamados "Anos de Chumbo", numa atmosfera de rigorosa censura dos produtos culturais. No dia 31 de março de 1964, um golpe pôs fim à frágil democracia brasileira, dando início a uma ditadura militar. Temendo um golpe de esquerda do então presidente João Goulart, os militares tomaram o poder, com apoio de boa parte da população influenciada pela mídia. $\mathrm{O}$ início da censura no Brasil ocorreu durante o chamado "milagre econômico", fase em que o país teve um crescimento significativo. A censura foi um dos acontecimentos mais marcantes, e mostrou a rigidez do regime autoritário. $\mathrm{O}$ controle governamental era intenso, com a proibição explícita da divulgação de notícias contra a ditadura militar, assim como eram violentas as formas de perseguição.

A partir da promulgação do Ato Institucional Número 5 (AI-5) em 1968 inaugurou-se a pior fase da repressão militar. O AI-5 foi decretado pelo presidente Costa e Silva e cancelava todos os dispositivos da Constituição de 1967 que pudessem ser usados pela oposição. $\mathrm{O}$ Conselho Superior de Censura foi criado para julgar os órgãos de comunicação que não cumprissem as leis, podendo ser fechados imediatamente. Após o AI-5, todos os veículos de comunicação deveriam ter suas pautas aprovadas pelos militares, antes de serem publicadas. As agências de notícias eram sujeitas à inspeção local por pessoas autorizadas. $\mathrm{O}$ regime militar usou de critérios polí- ticos para censurar o jornalismo. Muitos materiais foram censurados. Algumas reportagens de publicações impressas eram vetadas e, nos trechos deixados em branco, eram publicadas receitas culinárias ou poemas. $\mathrm{O}$ órgão responsável pela censura dos meios de comunicação era o Contel, comandado pelo Serviço Nacional de Informações (SNI) e pelo Departamento de Ordem Pública e Social (DOPS).

A violência do regime era notada nos confrontos policiais e nos desaparecimentos de perseguidos políticos sem motivo aparente. Mas nem todos percebiam as proporções reais de tudo isso. Durante o AI-5, a censura vetou cerca de seiscentos filmes, peças de teatro, programas de rádio, novelas, músicas. Muitos artistas e compositores tiveram suas obras censuradas e foram perseguidos. A televisão funcionou como instrumento efetivo de controle social, favorecendo a propaganda política estatal e promovendo a difusão de uma história pré-fabricada, e a disseminação da versão dos fatos controlada pela censura.

Foi nesse ambiente hostil que Osman Lins enveredou na aventura televisiva, com a produção de três textos escritos, roteirizados e adaptados para o programa "Caso Especial" da Rede Globo: "A ilha no espaço", "Quem era Shirley Temple?" e "Marcha fúnebre", reunidos e publicados por Raul Wasserman, diretor da Editora Summus, em 1978. Foram produzidos, ao todo, 172 episódios, com cerca de uma hora de duração cada, 
entre 10 de setembro de 1971 e 5 de dezembro de 1995, com periodicidade variada. Os "Casos Especiais" eram modernizações do antigo formato do teleteatro, com cenas em estúdio, apresentando uma história completa por episódio. Os textos podiam ser inéditos, mas, em geral, consistiam de adaptações literárias em segunda mão, de contos, romances e peças teatrais de autores consagrados, como Machado de Assis, Graciliano Ramos e Jorge Amado, inexistindo à época a profissão do roteirista de TV no país.

Fascinado pela proposta, Osman Lins não apenas cedeu seus originais para as adaptações: assumiu ele mesmo o desafio de aprender as técnicas de expressão do meio audiovisual, redigindo de próprio punho os seus episódios, e gabando-se, inclusive, de ter sido "o primeiro dos autores adaptados a produzir um texto diretamente pensado para a televisão". $\mathrm{O}$ primeiro programa gravado e exibido totalmente em cores da televisão brasileira foi um "Caso Especial": o episódio "Meu primeiro baile", transmitido em 31 de março de $1972 .{ }^{2}$ Em 1979, o programa abandonou a grade da Rede Globo, sendo substituído por "Aplauso", que apresentava teleteatros. Nos dois anos seguintes foram exibidos apenas três episódios, até que, em 1983, a atração voltou a ser transmitida com regularidade. Entre 1984 e 1987, houve uma nova interrupção no programa, que só teve dois episódios exibidos. De 1988 até 1995, ano no qual o programa encerrou definitivamente, passou novamente a ser emitido com período regular, integrando a "Quarta Nobre".

A produção de textos curtos para o suporte televisivo do "Caso Especial" obrigou o autor a um novo desafio: abandonar a sofisticação estilística criada aos moldes da escrita oulipiana francesa, que teria inspirado a coletânea de narrativas Nove, novena (1966) e o romance Avalovara (1973). A compreensão de que o "hermetismo" desses procedimentos não corresponderia ao horizonte de expectativas da recepção massificada prevista para o incipiente teleteatro nacional teria levado o escritor a explorar outros caminhos; mais próximos, talvez, das soluções encontradas pelo mestre da literatura de mistério e suspense, Edgar Allan Poe. Como se sabe, os contos de Poe com o personagem C. Auguste Dupin forneceram a base para as futuras histórias de detetive da literatura, o gênero de massa por excelência da modernidade.

Tal empreitada teria levado o autor, também, a um maior aprofundamento nos problemas levantados pela incipiente indústria cultural no Brasil, motivando-o a produzir artigos inspirados pelos filósofos e sociólogos alemães da Escola de Frankfurt - à qual pertencia Walter Benjamin (1985), autor do famoso ensaio "A obra de arte na era da sua reprodutibilidade técnica", que tantas luzes ainda trazem às reflexões sobre a autonomia e o poder crítico das obras artísticas na sociedade capitalista industrial e pós-industrial. O termo "indústria cultural" foi empregado pela primeira vez no capítulo 
"O iluminismo como mistificação das massas", no ensaio Dialética do esclarecimento, de Adorno e Horckheimer, escrito em 1942 e publicado em 1947.

Para esses pensadores, a autonomia e o poder crítico das obras artísticas derivam de sua oposição à sociedade de massa. No entanto, a fácil assimilação comercial dessas obras acabou corroendo seu valor contestatório. A máquina capitalista de reprodução e distribuição da cultura estaria apagando, aos poucos, a arte erudita e a arte popular, neutralizando o potencial crítico dessas duas formas artísticas ao impedir tanto a criação livre de seus produtores como a participação intelectual de seus consumidores. Como disse Osman Lins:

Desaparece, no seio da indústria cultural, a maior satisfação do artista, que é a de se identificar com a sua obra, isto é, de se justificar através da sua obra, de fundar nela sua própria transcendência. Margem, por assim dizer, inexistente, na mass media, de afirmação e desafio. Padronização inflexível, subserviência às expectativas, ou seja, fusão estática com o público, lisonjeado sem o mínimo pudor (LINS, 1969, p. 198).

Essa indústria encorajaria, portanto, uma visão passiva e acrítica do mundo, fomentando continuamente necessidades artificiais e superficiais a serem rapidamente satisfeitas, de modo a promover a formação de um público hedonista e pouco exigente, desestimulado para 0 esforço pessoal e para os desafios propostos por uma nova experiência estética. Como diria Guy Debord: "O espetáculo é o mau sonho da sociedade moderna acorrentada, que ao cabo não exprime senão o seu desejo de dormir. O espetáculo é o guardião deste sono" (1997, p. 19).

\section{$\mathrm{O}$ isolamento do escritor e a escrita como resistência}

A indústria cultural tem boas saídas para repelir as objeções feitas contra ela como as contra o mundo que ela duplica sem teses preconcebidas. A única escolha é colaborar ou se marginalizar.

... A indústria oferece ao consumidor que viu culturalmente dias melhores 0 sucedâneo da profundidade há muito

liquidada, e, ao espectador comum, a escória cultural de que deve dispor por motivos de prestígio. ... Aquele que resiste só pode sobreviver integrando-se.

(ADORNO, 2002, p. 25).

Que tem de fazer o escritor? Jamais colaborar com o outro lado, com os inimigos da literatura. Não colaborar em caráter permanente com rádio, TV, cinema industrial. Entrar nesses campos, mas como sabotador. Orientar-se pela censura e ludibriá-la. Bater-se, por todos os meios possíveis, como faço neste momento, pois estou aqui lutando por uma aproximação com possíveis leitores pela elucidação das suas posições e de sua tarefa.

Osman Lins (Arquivo IEB/USP, 1972)

Em seu ensaio Guerra sem testemunhas, Osman Lins reflete profundamente sobre a situação do escritor no mundo contemporâneo, num contexto geral que proclamava a morte do romance e numa realidade local dominada pela repressão política à criação e ao pensamento. Segundo Ana Luiza Andrade: 
A ensaística de Lins distingue-se por sua preocupação cultural. Guerra expressa a missão cultural do escritor no mundo, descrita em termos de um combate sem tréguas e sem possibilidades de reconhecimento, pois, como ele mesmo diz, o "mundo necessita de seus escritores na exata medida em que tende a negá-los, pelo sacrifício ou pelo esquecimento" (GST, p. 251). Esta posição marginalizada do escritor em relação ao mundo é explicada por fatores condicionantes da produção literária no Brasil e na nossa época em geral: a indústria editorial (em "O escritor e o editor"), a censura e a crítica (em "O escritor e as várias formas de crítica"), o livro (em "O escritor e o livro"). No último capítulo, "O escritor e a sociedade", Osman Lins resume estes problemas ou obstáculos exteriores que pressionam mais diretamente o escritor no Brasil expondo claramente a temática social (ANDRADE, 1987, p. 54).

Além de problematizar a indústria editorial interessada sobretudo nos lucros, Osman Lins ataca frontalmente a censura vigente na época, sobre a qual afirma: "Não temos força bastante para destruir a Besta, mas a inquietamos. Ela galoparia sobre o mundo com mais desembaraço - e talvez o devorasse - se não existíssemos" (LINS, 1974, p. 237). Para Lins, uma sociedade tolhida pelas imposições da censura, por maiores que sejam seus avanços noutros campos, sofrerá uma esclerose precisamente nas fontes em que pode renovar-se.

Entretanto, não é à censura que o autor atribui o maior problema da perda de espaço da literatura no mundo: é à indiferença dos leitores, considerada "o principal óbice à criação literária". "Uma indiferença que é a nossa morte" - afirma ele, preso na solidão de sua trincheira, na sua guerra sem testemunhas, movida por um incondicional amor à palavra. A instituição acadêmica, segundo ele, também concorre para o declínio da qualidade das produções culturais, encontrando-se os professores minados pelo tédio e pelo desencanto com o seu objeto. Apesar do quadro desanimador, Osman Lins defende veementemente o escritor que se recusa à conquista do êxito no sentido mundano e materialista. Nesse aspecto, alinha-se à tendência mais recentemente encabeçada pelo espanhol Enrique Vila-Matas, que vai buscar na pulsão negativa do personagem Bartleby, de Herman Melville - o copista que se recusa a copiar, causando uma reviravolta na vida de seu patrão, um advogado de Wall Street - inspiração para uma escrita em suspenso.

Como no texto de Jean de La Bruyère posto na epígrafe no seu livro Bartleby e Companhia, Vila-Matas defende que, enquanto "[...] a glória ou o mérito de certos homens consiste em escrever bem, a de outros consiste em não escrever" (2004, p. 7). Levada ao extremo noutra de suas obras, Suicídios exemplares (2009), a negação, dessa feita da própria vida, reitera a ideia da resistência:

[...] a possibilidade do suicídio, essa faísca de mistério regozijante com a qual o projeto de um morrer original, ou tortuoso, ou sofisticado, ou cruel, acende uma vida apagada e a faz reviver, tornando-a tensa de energia, excepcional, apaixonante, como a corda de aço de onde os equilibristas nos fazem perder o fôlego (PAULS apud VILA-MATAS, 2009, não paginado).

Os escritores desistentes ou suicidas elencados nessa obra são sempre fracassados, ou seja: não conseguem morrer. A 
ideia de não conseguirem se matar sugere incapacidade, fraqueza, impotência. $\mathrm{E}$, no entanto, é justamente essa impossibilidade que coloca os personagens em ação, que os enche de inspiração, humor, ansiedade, adrenalina. Como diz Alan Pauls no prefácio à obra:

\begin{abstract}
Sofisticada ou impulsiva, ponderada ou captada no ar em um instante de tédio, a ideia do suicídio nunca é um signo de derrota. É um princípio de potência: algo na vida range, se abre e começa a ser possível - algo desconhecido, que até então não tinha rosto nem forma, e que agora, de repente, parece exercer uma sedução irresistível - quando alguma das criaturas que povoam estas páginas se deixam possuir pela ideia de se matar. Isto é o bel morir: a deliciosa, a absurda toxicidade estética que um sonho de morte bem sonhado inocula na vida que foi chamado a ceifar (PAULS apud VILA-MATAS, 2009, não paginado).
\end{abstract}

Esses suicídios simbólicos jamais são frutos de uma desistência, mas o seu oposto. A insistência na qual se encarna a grande vontade que anima toda a ficção: a vontade de viver uma vida diferente. Essa vontade - também ancorada a um suicídio simbólico - atravessa a história do personagem Cláudio Arantes Marinho, bancário, casado, com quarenta e um anos de idade, desaparecido em setembro de 1958 do seu apartamento no $18^{\circ}$ andar de um prédio de luxo construído em Recife: o majestoso "Edifício Capibaribe".

Escrito e reescrito por Osman Lins desde os anos 1960, o conto "A ilha no espaço” será o primeiro texto adaptado por ele para a televisão, num episódio da série "Caso Especial" da Rede Globo, levado ao ar em 1975 e em 1978, quando foi também publicado, na versão conto, pela editora Summus, que reuniu os três textos do autor transformados em noveletas televisivas. Nesse conto, um dos poucos na sua carreira voltado para o gênero de massa por excelência - o policial -, a frustração do personagem ecoa também a do autor, que ganhou a vida como funcionário público, como confessa no seu ensaio Guerra:

Em vinte anos, segundo calcula, passou, lidando com fichas, memorandos, arquivos de madeira, cifras indicativas de fortunas alheias e quase sempre iníquas, máquinas de calcular, formulários, carimbos e protocolos borrados, 28.800 horas, não computando fins de semana e férias. Atribuindo-se ao dia dezesseis horas, descontadas as oito de repouso, passou exatamente, em vinte anos, sessenta meses encerrado num Banco, sessenta meses em que não escreveu, não aprendeu, não pôde locomover-se, nada colheu do que o mundo oferece, não viveu (LINS, 1974, p. 29).

Tal como o Bartleby de Melville, retratado em transe a olhar paralisado através da janela do escritório que se abre para um vão sombrio e uma parede de tijolos - sem esperança e sem futuro ,- o escritor real e figurado neste conto é um personagem aprisionado a uma vida estéril e artificial, que não lhe diz respeito, mas da qual não consegue se desvencilhar. Sua escravidão se estende à vida privada, onde se sente explorado por uma família ambiciosa, mulher e filhas desejosas de habitar um imóvel muito acima de suas posses. Para agradá-las, contudo, endivida-se, adquire o apartamento cobiçado, cenário do enredo 
de ação e suspense que se desenrolará a partir da mudança.

É bem verdade que o autor já visitara esse tipo de enredo em alguns momentos de sua carreira. Mas a sua escrita, nesses exercícios, deveria mais a um Jorge Luis Borges do que a um Edgar Allan Poe. Apesar de Borges ser devedor de Poe - como de resto o são todos os herdeiros do "Assassinatos na rua Morgue" - narrativa de ficção que deu origem ao gênero policial no século XIX, inaugurando a figura emblemática do detetive Dupin -, o caminho seguido pelo argentino desvia-se num sentido erudito e filosófico da história de enigma, enquanto o caminho aberto pelo norte-americano vai francamente no sentido da ficção massificada de mistério, com todos os ingredientes de apelo e vulgaridade que depois inflamariam a literatura de grande consumo e os enlatados em série produzidos para a televisão.

Poe, muito mais do que Borges, parecia pressentir o futuro da indústria cultural e não teve escrúpulos de incorporar a sua sistemática em seu próprio benefício. Segundo Adorno:

A indústria cultural pode se vangloriar de haver atuado com energia e de ter erigido em princípio a transposição - tantas vezes grosseira - da arte para a esfera do consumo, de haver liberado a diversão da sua ingenuidade mais desagradável e de haver melhorado a confecção das mercadorias. Quanto mais total ela se tornou, quanto mais impiedosamente obriga cada marginal à falência ou a entrar na corporação, tanto mais se fez astuciosa e respeitável (2002, p. 30).
A construção de "Dois caminhos que se bifurcam", de Borges, por exemplo - com suas idas e vindas no labirinto de um crime anunciado e descrito com requintes especulativos e fantásticos -, difere completamente da estrutura dos contos do detetive Dupin. Como diz Lucas Antunes Oliveira (2016, p. 7), as narrativas policiais ditas metafísicas, como as de Borges e da maioria de seus herdeiros hispano-americanos, de Julio Cortázar a Roberto Bolaño, e até do brasileiro Osman Lins dos contos e narrativas anteriores à experiência do roteiro televisivo:

[...] subvertem o modelo formal da narrativa policial para tratar da ruína dos discursos ideológicos da modernidade, da experiência da vivência em um mundo no qual é impossível encontrar um sentido último e totalizante, e das diversas manifestações do Mal e do crime em nossa realidade, dando destaque à figura do intelectual como novo detetive (OLIVEIRA, 2016, p. 92).

Mas na sua vertente original, o gênero pretendia guiar-se para a indústria do entretenimento "fácil". Ainda segundo Oliveira, o policial pretendia apresentar:

[...] um mistério aparentemente insolucionável que rompe com a ordem do cotidiano e instaura o desconhecido; a polícia oficial incapaz de desvendar o mistério; a figura do excêntrico detetive amador que resolve o enigma por meio do método dedutivo racional; a história narrada por um companheiro do detetive, menos sagaz do que este; o motivo do quarto fechado; o reestabelecimento da ordem ao final da narrativa; além de outras convenções. Alguns teóricos discordam dessa posição, alegando que, apesar de tudo isso, Poe não foi capaz de dar uma forma concreta ao gênero, cabendo esse papel a Arthur Conan Doyle, com seu Sherlock Hol- 
mes. Contudo, se não é possível determinar com exatidão o ano em que surgiu o romance policial, ao menos se pode dizer com certeza a época e a mentalidade ao qual ele pertencia: o século XIX e a mentalidade burguesa e moderna (OLIVEIRA, 2016, p. 92).

Para Adorno, a arte "leve" como tal, a distração, não é uma forma mórbida e degenerada, apesar do seu formato fútil. A temática do crime está intimamente relacionada com as mudanças sociais e ideológicas que a derradeira ascensão da burguesia ao poder e o implemento da industrialização nos países desenvolvidos trouxeram ao século XIX. As novas relações sociais, fundamentadas na exploração massiva da classe trabalhadora pela burguesia, obrigada a trabalhar por encomenda em condições inumanas, insuficientemente remunerada, mal alimentada e condenada a viver na miséria e no amontoamento das grandes cidades, fomentaram o incremento do delito urbano e a consciência pública do mesmo, e, consequentemente, a insegurança dos cidadãos, despertando o interesse de grandes escritores como Dostoiévski, Stendhal, Balzac e Dickens.

Fugindo ao realismo crítico desses autores, porém, Poe estabelece as bases de uma narrativa de consumo mais descritiva e menos reflexiva, mais adequada a um público cansado e desmotivado, que busca na literatura um modo de alienação da sua realidade, segundo a visão dos ensaístas da Escola de Frankfurt:

A arte séria foi negada àqueles a quem a necessidade e a pressão da existência tornam a seriedade uma farsa e que, necessariamente, se sentem felizes nas horas em que folgam da roda-viva. A arte "leve" acompanhou a arte autônoma como uma sombra. Ela representa a má-consciência social da arte séria. ... A diversão é o prolongamento do trabalho sob o capitalismo tardio. Ela é procurada pelos que querem se subtrair aos processos de trabalho mecanizado, para que estejam de novo em condições de enfrentá-lo. ...O prazer da violência contra o personagem transforma-se na violência contra o espectador, o divertimento converte-se em tensão (ADORNO, 2002, p. 30-35).

"O divertimento promove a resignação que nele procura se esquecer" - dizem os filósofos. O modelo da narrativa esquemática de Poe, com seus apelos sensoriais maiores do que as provocações intelectuais, já apontava para a estrutura das narrativas televisivas, cujo ritmo vertiginoso, cenas superpostas e espetaculosas, economia de diálogos, exibição indiscriminada de sexo e violência - a intervalos eivados pela agressividade da propaganda -, criariam um produto incapaz de viabilizar a serenidade e o tempo necessários à construção de uma ideia.

A comparação de três exemplos extraídos da produção osmaniana na categoria "conto" permite que se estabeleça como o autor dominava e manipulava a estrutura do gênero, e como revelava consciência de sua necessária adaptação para o novo suporte midiático. Seu primeiro livro, $\mathrm{Os}$ gestos (1957), reúne contos tradicionalmente concebidos, mostrando o conhecimento do autor das regras expostas para o gênero, de André Jolles (Formas simples) a Ricardo Piglia (Formas breves), que o italiano Ítalo Calvino (2015) subsome nas suas Seis propostas para o próximo milênio: "leveza", "rapidez”, “exatidão", 
"visibilidade", "multiplicidade" e "consistência". Embora escritas para falar da literatura em geral na era pós-moderna, os títulos desses capítulos - que foram as conferências ministradas (à exceção da última) pelo escritor na Universidade de Harvard às portas do ano 2000 - sumarizam as características esperadas para a narrativa curta.

Em Os gestos encontramos uma amostra de um conto "policial": "O perseguido ou conto enigmático". Conciso - não mais que quatro páginas -, discorre com rapidez, acentuada pelo fato de a narrativa ocorrer no interior de um trem em movimento, sobre as percepções múltiplas de um narrador que observa um homem suspeito, sentado à sua frente. $\mathrm{O}$ recurso à visibilidade é intenso: imagens da morte se sobrepõem, desde $o$ aspecto do próprio homem que dorme, cuja cabeça "oscila como a de um cadáver recente", até as sugestões de um crime nunca revelado, que perpassa a memória do narrador: os sulcos na madeira que lembram os galhos onde "alguém enforcou uma criança", e uma sucessão de "visões": a de um ataúde pequeno estendido numa sala, a de uma corda sobre um lençol de criança, a de uma chave ou atiçador "balançando sem cessar como um corpo de enforcado ao vento", a silhueta de uma garota de pé sobre uma janela, vislumbrada na passagem do trem por um grupo de pequenas casas: "como um boneco de papel, seus braços pendem, seu corpo balouça, balouça no ar", e um nome: "Luci".
Entrecortadas pela velocidade do veículo, as cenas do passado, resgatadas da memória e reconstruídas a partir do choque com as impressões do presente na cabine do trem, fornecem apenas flashes de uma história não revelada. $\mathrm{O}$ relato sugere que alguma suspeita paira sobre $o$ sujeito observado. Entretanto, o narrador descreve a presença fantasmagórica de um "velho magro e comprido", que corre ao lado do trem, com ódio e imensa sede de vingança. Esse velho encarna uma culpa que se pressente no observador narrador: "Felizmente ele corre, corre sem cansar, mas não pode apanhar o trem em velocidade.”. Percebe-se que o próprio narrador, e não o homem observado, é que tem algo a esconder. $\mathrm{O}$ leitor infere que $o$ observador e o observado talvez sejam a mesma pessoa, e que o "trem" talvez seja uma imagem da própria fuga do criminoso de sua consciência pesada. No final, o narrador é apanhado por três homens que vêm ao seu encontro na estação sombria.

Toda a atmosfera do conto resgata $o$ clima do cinema noir, subgênero de filme policial que teve seu ápice nos Estados Unidos, entre os anos 1939 e 1950. A expressão foi aplicada pela primeira vez a um filme pelo crítico francês Nino Frank em 1946, por analogia com os romances policiais da Série Noire, uma coleção criada por Marcel Duhamel para a Gallimard em 1945, cujos livros tinham capa preta, e cujas histórias se constituíam, em sua maioria, em traduções de histórias produzidas por Dashiell Hammett, Raymond Chandler, James 
M. Cain, Cornell Woolrich e outros especialistas anglo-saxões. A expressão era desconhecida dos diretores e atores à época em que foram produzidos esses clássicos, tendo sido introduzida posteriormente pelos críticos de cinema. Os filmes eram rodados em preto e branco, segundo a estética cinematográfica do expressionismo alemão, afeita à tensão e aos jogos de luz e sombra. Segundo A. C. Gomes de Matos:

Tomando emprestado do cinema expressionista alemão e o estilo visual dark, que oferece um correlativo preciso para suas narrativas pessimistas, inspiradas na tradição literária hard boiled, os filmes noirs revelam o avesso daquela versão glamouriza$d a$ da vida nos Estados Unidos apresentada por Hollywood. Mostram a confusão, o medo, a ansiedade e a paranoia existentes em um momento específico da história americana. Sexo, ganância e poder tendem a ocupar o lugar do amor. Os filmes sondam as áreas mais sombrias da mente, pondo em foco as obsessões e as neuroses que geram a violência, o niilismo, a crueldade, a luxúria. As autoridades estabelecidas são corruptas e a metrópole habitada por pessoas viciadas e amorais (GOMES DE MATOS, 2001, p. 12).

Apreciador confesso da sétima arte, não é de duvidar que Osman Lins, em sua empreitada "sabotadora" da indústria cultural, também tenha recorrido a algumas técnicas do filme noir - que retrata uma sociedade na qual o sonho americano de sucesso é invertido e a alienação e o fracasso são os tons dominantes - para compor esse breve e tenso conto policial "enigmático".

Já em Nove, novena (1966) - coletânea de textos que o autor faz questão de identificar como "narrativas", fugindo à estética do conto tradicional, Osman Lins reelabora muitas de suas histórias publicadas uma década antes. Segundo afirma Sandra Nitrini (1987), em Poéticas em confronto, enquanto bolsista da Aliança Francesa nos anos 1960, o autor não só teve a oportunidade de ler as obras do experimentalismo francês do nouveau roman, como de entrevistar os grandes expoentes do movimento, como Michel Butor e Alain Robbe-Grillet. É conhecida a parceria desse último com o diretor Alain Resnais e com a criação do movimento cinematográfico da nouvelle vague, não sendo improvável que Osman Lins tenha tido acesso, também, a essas produções.

Chama a atenção, nas narrativas de Nove, novena, a fuga ao critério da concisão aplicado ao conto. Tem-se, nessas peças literárias, um exercício de excesso, tanto na extensão do texto quanto no seu flagrante ornamentalismo decorativo. Consideremos brevemente, aqui, uma dessas narrativas: "Conto barroco ou unidade tripartita”. Das regras de Ítalo Calvino restam, neste texto, apenas a multiplicidade e a visibilidade, em detrimento da leveza, rapidez, exatidão e consistência. A palavra "barroco", no título, não é casual. O enredo é o elemento menos importante, afundado numa escrita rebuscada, plástica e suntuosa, e fragmentado em três opções separadas pela conjunção "ou", de modo a assinalar a indecisão do autor como uma característica determinante no processo da escritura. Não temos mais um demiurgo no controle da história, mas o agenciamento 
de perspectivas múltiplas sobre um fato, ou vários; o que, ao contrário de conduzir à verdade e à solução do enigma, mais se distanciam dessa possibilidade.

Neste aspecto, a narrativa implode o esquema corrente do conto policial, que tende a resolver-se na solução do mistério, na revelação do criminoso e na sua merecida punição, restabelecendo, assim, a ordem social rompida. Numa franca, deliberada e calculada guerra contra o sistema nivelador da cultura e da liberdade de pensamento, Osman Lins ataca frontalmente as estratégias da indústria, produzindo em suas "narrativas" a desautomatização dos "gestos". Conforme Adorno:

As massas desmoralizadas pela vida sob pressão do sistema e que se mostram civilizadas somente pelos comportamentos automáticos e forçados, das quais gotejam relutância e furor, devem ser disciplinadas pelo espetáculo da vida inexorável, e pela contenção exemplar das vítimas. A cultura sempre contribuiu para domar os instintos revolucionários bem como os costumes bárbaros. A cultura industrializada dá algo mais. Ela ensina e infunde a condição em que a vida desumana pode ser tolerada. $\mathrm{O}$ indivíduo deve utilizar o seu desgosto geral como impulso para abandonar-se ao poder coletivo do qual está cansado. As situações cronicamente desesperadas que afligem o espectador na vida cotidiana transformam-se na reprodução, na garantia de que se pode continuar a viver (2002, p. 57).

Frontalmente contrário a esse papel da "arte", Osman Lins busca promover o oposto, o desconforto do público com a realidade infamante da vida que lhe é imposta. Apela, assim, para a surpresa do espectador na quebra da narrativa linear, e para o uso da metalinguagem na desconstrução do ilusionismo mimético, responsável pela alienação do receptor de sua realidade, pela imersão no realismo fictício do livro/filme. A nouvelle vague, que não era considerada uma "escola" por seus idealizadores, fazia a construção cinematográfica tendo consciência do cinema enquanto aparato. A sátira sobre a própria linguagem cinematográfica (onde se firmam os clichês visuais) é percebida em filmes que se caracterizam como adeptos do gênero. As cenas focam o aspecto psicológico dos personagens, suas impressões cotidianas e banais, levando o sujeito a se sobrepor à lógica das cenas.

A leitura de "Conto barroco ou unidade tripartita" sugere uma influência desse estilo cinematográfico. A presença algo irônica da palavra "conto" chama a atenção, quando se considera o alerta de Osman Lins sobre a natureza exótica dos textos, exemplarmente definidos por João Alexandre Barbosa em seu prefácio à obra:

Quer fazendo transparecer estruturas pictóricas, quer desenvolvendo linhas de um verdadeiro atonalismo musical, as narrativas não são dadas ao leitor, mas, permitido o trocadilho, dados, conjuntos de sinais linguísticos ou tipográficos, por onde o leitor se sente escoar durante a leitura, como que fisgado numa teia de construções superpostas. Novelos de significados (BARBOSA, apud LINS, 1987, p. 4).

Nessa história, o crime ainda está por acontecer, ao contrário do que se observa no conto policial clássico, que trata da investigação retrospectiva de um evento passado, pela análise das "provas" e "pistas". Não há, ainda, um cadáver - o 
que contraria mais profundamente a regra policialesca: "Não há crime sem cadáver". Viva, a vítima se desdobra e se multiplica ao longo da narrativa: há os duplos José Gervásio e José Pascásio, primos de grande semelhança. Há o velho pai de José Gervásio, que se oferece para morrer em seu lugar. Há as testemunhas de acusação, como a negra amante de José Gervásio e mãe do seu filho, morto recentemente, a quem ele negou reconhecimento e assistência, gerando grande ressentimento na mulher. $\mathrm{E}$ há o assassino que não se oculta, antes, se impõe abertamente, designando-se como "matador profissional", contratado a soldo, hábil na sua função e destituído de quaisquer pruridos íntimos morais ou de consciência. Extremamente jovem, não tem nome, mas deita-se com a negra a quem encomenda a traição da vítima, valendo-se de sua dor. Deita-se na mesma cama onde morreu o filho enjeitado de José Gervásio, que motiva a vingança doída da negra desprezada e humilhada, descrita com grande beleza plástica e exuberância de cores.

O assassino guarda semelhanças com a vítima: também tem um filho morto a quem abandonou. A vítima ora é descrita como um ser implacável, homem desprezível que deseja desfazer-se da amante para casar-se com outra; ora como um ser explorado por pais desprezíveis, que lhe impunham como ganha-pão a tarefa de representar o imolado pelo interior da Bahia, repetidamente, ludibriando os incautos. As causas do assassinato são desconhecidas, assim como os mandantes do crime. O cenário principal é a cidade histórica de Ouro Preto, em Minas Gerais. Entretanto, há no enredo verdadeiras ekphrasis das obras do Aleijadinho dispostas no santuário do Bom Jesus de Matosinhos, em Congonhas, sugerindo que a temática cristã impera no bojo dessa história "policialesca" transplantada para a realidade moral, ética e estética do Brasil profundo, ignorante das leis e princípios urbanos, laicos e estrangeiros de outros territórios dominados pela ideologia maquínica do desenvolvimento industrial. $\mathrm{Na}$ realidade encenada, os aspectos psicológicos, afetivos, filosóficos e humanos é que estão em jogo, muito mais do que as considerações rasteiras e as intenções pedagogizantes do gênero policial, que versa sobre a natureza das regras de conduta social estabelecidas pelos homens, a investigação sobre os efeitos de sua eventual ruptura e a exemplaridade da condenação dos elementos desviantes.

Com sua riqueza ornamental e conteudística, o ilusionismo barroco confronta, nesta soberba narrativa erudita e popular, a indigência do ilusionismo produzido pela estandardização das técnicas de produção da cultura de massa. Tal preciosismo, posto em prática no "Conto barroco ou unidade tripartita", sofre profunda guinada na realização do roteiro para a televisão por Osman Lins, como se pode perceber pela análise do conto "A ilha no espaço", exemplo de sua percepção da adequabilidade da forma ao meio. Assim, encontramos no enredo 
dessa obra um vínculo muito mais explícito ao conto policial de Edgar Allan Poe:

Quatro das testemunhas, tendo sido convocadas, depuseram que a porta do quarto em que foi encontrado o corpo de Mademoiselle L'Espanaye estava trancada por dentro quando o grupo chegou até lá. Ao forçarem a porta, não viram ninguém. As janelas, tanto da sala da frente como do quarto dos fundos, estavam com os postigos fechados e firmemente trancadas por dentro. A porta que dava da sala da frente para o corredor de acesso estava trancada, com a chave do lado de dentro (POE, 1997, p. 68).

O cenário do crime em "A ilha no espaço" é descrito de modo semelhante:

A princípio, acreditou-se que ele houvesse morrido: seu apartamento no $18^{\circ}$ andar estava fechado por dentro, a trinco e chave. Repórteres vieram, gente da polícia, e arrombaram a porta: a janela da frente, que dava para o rio e para o mar, estava aberta, a cortina barata esvoaçando, mas não havia ninguém no apartamento. Supor que um homem com a sua idade e não afeito a exercícios físicos pudesse haver descido numa corda de tão grande altura, era absurdo. E depois, onde estava a corda? (LINS, 1978, p. 12).

Apesar da confessa intenção alegórica do texto - que confirmaria a história como uma melancólica alusão ao isolamento do escritor na cidade moderna -; e apesar do desejo confesso de Osman Lins de invadir o meio audiovisual na condição de "sabotador" do sistema; o que se observa é a criação de um texto mais raso que os anteriores, mais direto, sem a mesma elaboração estilística, de fácil e rápida leitura, e sem maiores exigências interpretativas. O recurso aos clichês do gênero de massa é evidente não só pela clássica cena do quarto trancado por dentro, mas pelo tom investigativo adotado na narração, e pela explicação final do mistério. Apesar de não incluir um detetive - uma vez que o foragido precisava escapar, a fim de recomeçar uma vida mais verdadeira e feliz -, o esquema geral da narrativa atende aos princípios do gênero policial. Eventualmente, durante a narrativa, Osman Lins flerta com o fantástico, particularmente com a vertente identificada como o "estranho" na definição de Tzvetan Todorov:

Sabemos que Poe deu origem à novela policial contemporânea, e esta cercania não é fruto da casualidade; frequentemente se afirma, por outro lado, que os contos policiais substituíram os contos de fantasmas. Esclareçamos a natureza desta relação. A novela policial com enigmas, em que se trata de descobrir a identidade do culpado, está construída da seguinte maneira: por uma parte, propõem-se várias soluções fáceis, a primeira vista tentadoras, que, entretanto, resultam falsas; por outra parte, há uma solução absolutamente inverossímil, a qual só se chegará ao final, e que resultará ser a única verdadeira. Vimos já o que emparenta a novela policial com o conto fantástico. Recordemos as definições de Soloviov e de James: o relato fantástico tem também duas soluções, uma verossímil e sobrenatural, e a outra inverossímil e racional. Na novela policial, basta que a dificuldade desta segunda solução seja tão grande que chegue a "desafiar a razão", para que estejamos dispostos a aceitar a existência do sobrenatural mais que a falta de toda explicação (TODOROV, 1981, p. 27).

Segundo o autor, a novela policial com enigmas se relaciona com o fantástico, mas é, ao mesmo tempo, seu oposto: nos textos fantásticos, inclinamo-nos, de todos os modos, pela explicação sobre- 
natural; enquanto a novela policial, uma vez concluída, não deixa dúvida alguma quanto à ausência de acontecimentos sobrenaturais. Por outro viés, essa comparação só é válida para um certo tipo de novela policial com enigmas (o local fechado) e um certo tipo de relato estranho (o sobrenatural explicado). Tal é o que acontece com o enredo de "A ilha no espaço": flerta-se com a dúvida crescente sobre as mortes que vão misteriosamente acometendo os moradores das torres gêmeas; depois, flerta-se com eventos inexplicáveis (toques de telefone, ruídos no elevador, lâmpadas acesas, canário que aparece morto) testemunhados pelo morador, o único que fica no prédio, atendendo à proposta dos proprietários que lhe oferecem o apartamento de graça caso lá permanecesse, atestando a improvável segurança do imóvel. Então, passa-se ao esclarecimento sobre a solução do enigma: o relato do procedimento de fuga do bancário, num plano mirabolante e inverossímil, fruto de um arriscado esquema para forjar o seu sumiço surreal; não dando margens, talvez, à vingança dos proprietários. Assegurava, assim, o patrimônio a uma família mesquinha e sem amor, da qual se desvencilhava com alívio e esperança de um recomeço.

Se a dúvida continua a persistir para os personagens do conto, ela absolutamente não existe para os leitores, que são plenamente esclarecidos. Sobre essa incursão num projeto tão distante de suas investidas anteriores e do seu conhecido engajamento à literatura de qualidade, ele confessa, em prefácio à publicação do texto pela editora Summus:

Foi-me oferecida, como a outros autores, a possibilidade de experimentar a televisão através da série "Caso Especial", que procura fugir à rotina dos enlatados e onde a terrível luta pela conquista de altos índices de audiência, se não desaparece, é atenuada. A oportunidade interessava-me, exatamente devido a este duplo aspecto: permitia-me a experiência e não gerava compromissos. ... Escrevi "A ilha no espaço" a intervalos mais ou menos amplos, vários desfechos, nenhum dos quais me satisfez. Por uma razão simples: a história, a meu ver, esgota-se o capítulo XI, beneficiando-se exatamente do que fica na sombra. Afinal, um mistério revelado é coisa morta. Entretanto, como este já foi divulgado em jornal, e como a adaptação para a TV em grande parte se apoiava nele, optei por conservá-lo na publicação (LINS, 1978, p. 6).

O que Osman Lins não confessa é a espécie de catarse que opera no âmbito dessa história, denunciando não só a aridez do trabalho burocrático imposto aos habitantes da cidade moderna, mas o esfacelamento das relações familiares, esgotadas nas questões financeiras; substituída a alegria de ser pela vaidade de ter, que é o verdadeiro "vírus" que se espalha nos corredores do espigão, envenenando a alma das pessoas. As figuras dos capitalistas frios e calculistas, com sua proposta cínica e indecorosa, perdem em crueldade na comparação com as figuras dos familiares mais próximos do protagonista, que celebram a decisão sacrificial do marido e pai de permanecer no prédio condenado, arriscando a 
própria vida, apenas para garantir a propriedade do apartamento.

Assim, para além da pirotecnia de superfície, esse despretensioso conto não consegue ocultar a indiscutível marca da agudeza crítica osmaniana. Em sua simplicidade e absoluta falta de ornatos, em sua deliberada indigência, o texto é profundamente amargo e gravemente acusatório. Preferiria, como é do seu estilo, concluir na penumbra, com a discrição que lhe é peculiar. Os que optassem por acreditar nos falsetes das notícias inverídicas - que acusavam a presença de contaminações exóticas e outras histórias - que o fizessem. Mas aos bons entendedores, o verdadeiro lamento se faria ouvir: a doença que atingia os moradores do "Edifício Capibaribe" - monumento de ostentação e poder incrustado na acanhada e humilde realidade recifense - era de ordem ética e anímica.

Assim, compreende-se que o capítulo XII parecesse não só desnecessário, mas até insultuoso ao autor, na medida em que transformava o seu personagem num inadvertido cúmplice do crime perpetrado pelos seus algozes. Supostamente, conferia-se a Claudio Arantes Marinho - não escapando, aqui, a clara alusão ao sobrenome da família detentora do império global que se instalava no Brasil - o "poder" de vingar-se, simbolicamente, do assassino confesso. Além de ser obrigado a ouvir a confissão do golpe perpetrado pelo capitalista - que envenenava envelopes enviando-os a esmo para os moradores desavisados, provocando mortes seriadas até o esvaziamento dos prédios por ele cobiçados, os quais viria a adquirir pela metade do preço -, ainda o submetia ao ridículo de uma encenação vulgar, digna da arrogância dos poderosos convictos de que o público já não reage às provocações. É como o "riso ruim" de que fala Adorno: "o riso ruim é o eco do poder como força inelutável. Ele vence o medo enfileirando-se com as instâncias que teme" (2002, p. 38).

Osman Lins, no entanto, deixa bem estabelecido que "este final não lhe dizia respeito". Referia-se ele ao trecho em que Marinho (transformado, aqui, não mais num alter ego do escritor "sabotador", mas num agente do sistema, pago por ele e a ele submisso: daí, talvez, a partilha do sobrenome, incorporado que foi à "família") pede ao rico assassino que sorria, e aperta um botão de uma câmera, estourando-lhe os miolos. O recurso, grosseiro demais para trazer a marca osmaniana, não passa de uma afirmação da impossibilidade de lutar. Talvez por isso, o rico assassino é cinicamente identificado, neste capítulo, como o "salvador" do ex-bancário: aquele que lhe permitiu evadir-se de uma vida monótona e triste, recomeçando em outro lugar. Ri-se, assim, mais uma vez, o rico assassino dos recursos fantasiosos e inúteis dos seus contraventores. Como afirma Adorno: 
$\mathrm{Na}$ falsa sociedade, o riso golpeou a felicidade como uma doença, arrastando-a na sua totalidade insignificante. Rir de alguma coisa é sempre escarnecer; a vida que, segundo Bergson, rompe a crosta endurecida, passa a ser, na realidade, a irrupção da barbárie, a afirmação de si que, numa ocasião social, celebra a sua liberação de qualquer escrúpulo. A coletividade dos que riem é a paródia da humanidade (2002, p. 39).

\section{Considerações finais}

Em relação ao roteiro do episódio, não se sabe se o diretor, Cassiano Gabus Mendes, chegou a adaptar o texto original de Osman Lins, ou se apenas fez anotações de planos de filmagem. No arquivo da Rede Globo já não encontramos nem a cópia do episódio nem a do roteiro. Osman Lins comenta, no prefácio à publicação da obra, que o capítulo XII, embora a seu contragosto, teria norteado a adaptação para a TV. O fato é que, modificada por Cassiano ou não, a narrativa precisou ser adaptada do formato conto para o formato roteiro, e é possível que o próprio Osman Lins tenha realizado esse trabalho, preferindo publicar a versão conto.
Figura 3 - Regina Viana e Cecil Thiré em "A ilha no espaço"

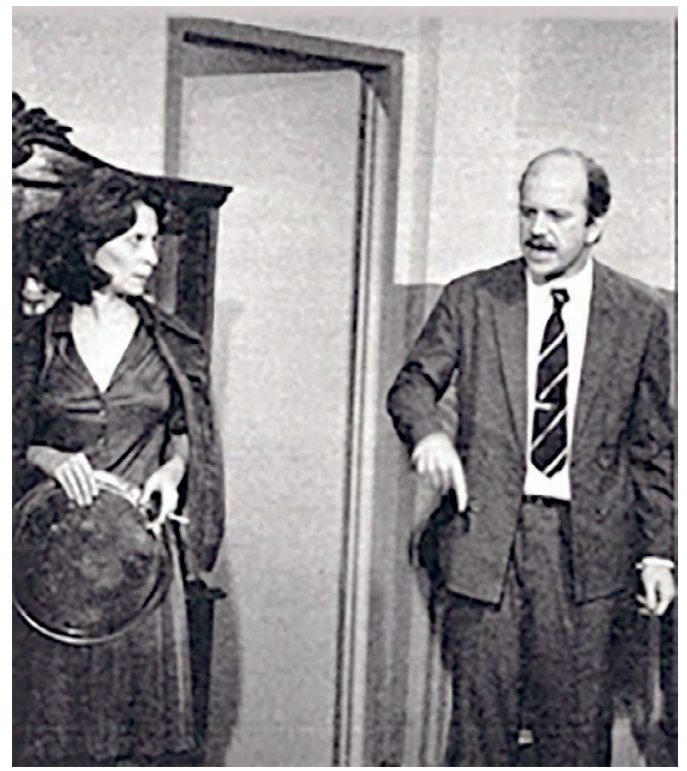

Fonte: Mendes (1975).

Figura 4 - Reportagem de Artur da Távola sobre o episódio

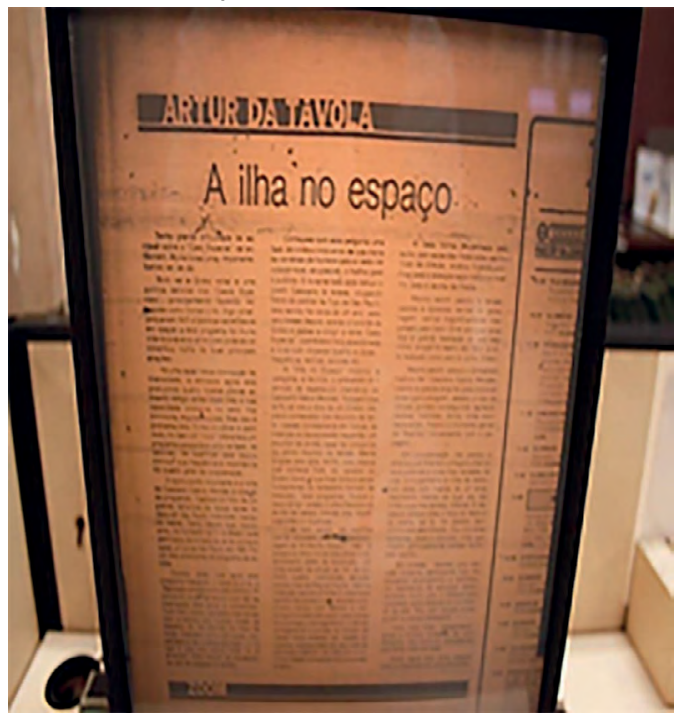

Fonte: Jornal O Globo (1975). 
Em 1/8/1975, no dia seguinte à estreia do "Caso Especial" em questão, o colunista do jornal $O$ Globo, Artur da Távola, publica uma resenha sobre o episódio. Apesar de analisar com mais afinco a direção de Cassiano Gabus Mendes, ele enaltece o nome de Osman Lins logo no segundo parágrafo:

Tenho grande dificuldade de escrever sobre o "Caso Especial" exibido anteontem. Muita coisa junta, importante. Vamos ver no que dá: bom ver a Globo voltando uma política definida nos "Casos Especiais", principalmente trazendo escritores como Osman Lins. Digo voltar, porque em 1975 a política da emissora em relação a este programa foi muito inferior à de anos anteriores onde ele se constituiu numa de suas principais atrações (TÁVOLA, 1975, p. 130).

No decorrer do artigo, Távola ressalta que "A ilha no espaço" contou com a habilidade técnica e dramática do diretor: "um escultor de atores capaz de colocá-los no ponto máximo da tensão latente exigida pela obra", pontuou o comunicador. Mais adiante, ele pondera críticas ao ritmo e aos excessos do episódio:

[...] excessivo ritmo inicial prejudicou o entendimento pleno da exposição: um corte errado da edição ao fim do primeiro quadro interrompeu abruptamente a fala de Regina Vianna: alguma indecisão estilística entre o tratamento realista dos atores e o do absurdo (o indicado) tornou sutil demais a simbologia buscada pelo autor como forma de expressar o esmagamento, o terrível esmagamento e solidão do homem de classe média enleado nas ilusões do sistema, hiperexcitado em seu nível de aspiração e sempre nas mãos de novos e mais hábeis portadores de promessas e bens (TÁVOLA, 1975, p. 130).
Artur da Távola percebe, na adaptação, a intenção de falar do isolamento, não só do escritor, mas do "homem de classe média enleado pela ilusão consumista". O fato é que a alegoria da prisão nas alturas, por assim dizer - criada por Osman Lins através da imagem do sujeito enclausurado num arranha-céu - funciona de maneira eficaz para traduzir uma forte percepção de abandono, desamparo, segregação e ostracismo, aberta a múltiplas leituras. Os dois imensos monólitos de pedra impõem-se, como protagonistas, tanto no conto como no filme, reduzindo o humano a um índice irrisório a eles escravizado. A vaidade e a ambição levam o sujeito a alugar seu destino e sua história às apólices de um banco.

No decorrer de seu texto, o colunista elogia ainda a inclusão de algumas cenas, como a de Arantes falando ao papagaio; mas critica veementemente a retirada de outras, como aquela em que o protagonista conversa com a filha. Suas observações mostram o quanto essa análise, escrita para o jornal, foi criteriosamente construída a partir da leitura comparada do texto e do filme. Reconhece o crítico, em sua leitura, a superioridade do conto em face da adaptação, sobretudo pela supressão do discurso na cena gravada, onde deveria, na sua opinião, "ter imperado porque estava muito bem escrito": 
Em compensação, não passou a cena na qual Arantes começa a olhar os seus parentes e dizer-lhes verdades de vida, principalmente à filha de dezesseis anos com marcas de um envelhecimento interior do qual ela não tinha culpa mas lavrava, infernal. $E$ não passou porque toda a força do texto e do drama, sei lá, me pareceu aqui minimizada pela direção. Era uma cena belíssima, onde o discurso tinha que imperar principalmente porque muito bem escrito (TÁVOLA, 1975, p. 130).

O desfecho do artigo dá a entender que o jornalista não só apreciou o valor literário dessa pequena e despretensiosa peça osmaniana, identificando a beleza das cenas e dos diálogos; mas também fez questão de registrar a sua percepção do papel que os textos de autores consagrados poderia exercer para uma (desejada!) reformulação qualitativa da programação levada ao grande público brasileiro:

Em síntese: fizeram uma televisão moderna, participante, fora dos esquemas arrumadinhos e certinhos, um espetáculo de estrutura aberta, deixando muito para o telespectador completar, como deve ser em se tratando de arte. Mas nem sempre conseguiram a clareza necessária. Uma nota final, indispensável: genial a música incidental de Julio Medaglia. Das melhores sonoplastias que tenho visto em tevê (TÁVOLA, 1975, p. 130).

Não há dúvidas sobre a natureza das expectativas de Artur da Távola, que consistiam numa efetiva cobrança por uma televisão "moderna": isto significando, surpreendentemente, uma programação de entretenimento acessível, mas bem trabalhada, com roteiros esteticamente concebidos, boa direção de arte, boa sonoplastia, e respeito pela inteligência do receptor, com a utilização de uma "obra aberta".

Esse belo artigo deve ter enchido Osman Lins de esperanças, pois se alinhava com as suas próprias ambições de ingresso no meio audiovisual como "sabotador", entre outras coisas, daquilo que Távola identifica com os "esquemas arrumadinhos e certinhos". Tais esquemas são apontados, inclusive, como os responsáveis por uma guinada, para pior, na condução do próprio "Caso Especial" naquele mesmo ano de 1975 - depois do que se supõe ter sido uma época de grande investimento no formato e no nível da programação. A entrada de Osman Lins é, portanto, saudada como um marco de "retorno", como a esperança de uma "volta" a um direcionamento que a emissora, infelizmente, já não considerava como prioritário ou desejável para os seus propósitos - como se verificaria a seguir.

\section{Osman Lins in television}

Abstract
Osman Lins (1924-1978), brazilian
novelist, short story writer and play-
wright, was a keen advocate of the
word and a staunch critic of the cul-
tural industry. In the 1970s, however,
at the invitation of Rede Globo, he
produced three scripts for the "Caso
Especial" television program, which
were adapted and displayed in the
prime time of the station. Unfortuna-
tely, this was one of his last works,
the author having died as a cancer


victim, leaving behind several unfinished projects, such as the novel Uma cabeça levada em triunfo, and his entrance - as a "saboteur", according to him - in the massive entertainment market that was growing fastly in Brazil during the military dictatorship. In this article, we comment on the author's foray into the police genre, from the analysis of one of his written texts for TV: "Uma ilha no espaço", published in 1978 by Summus.

Keywords: Osman Lins. Rede Globo's "Casos Especiais". Cultural Industry. "Uma ilha no espaço".

\section{Notas}

1 Uma experiência similar de alcance massificado, embora mais localizada, de uma notícia inverossímil já havia sido testada no âmbito do rádio, em 30 de outubro de 1938, no programa da Columbia Broadcasting System (CBS), na transmissão simulada de uma "edição extraordinária" com o aviso sobre uma suposta invasão de marcianos, coordenada pelo jovem escritor e diretor Orson Welles, desconhecido à época, que teria adaptado o livro de H. G. Wells, A guerra dos mundos, para uma radionovela. A "invasão" durou apenas uma hora - com todas as características do radiojornalismo às quais os ouvintes estavam acostumados -, mas marcou definitivamente a história do rádio, ajudando a CBS a bater a NBC, emissora concorrente, e levando pânico a incríveis dois milhões de pessoas em diversas cidades norte-americanas, que acreditaram piamente na veracidade da transmissão.

2 Em 1971, o governo baixou uma lei determinando o corte da concessão das emissoras que não transmitiam uma porcentagem mínima de programas em cores. Foi um período de transição, de mudanças e inovações nas televisões brasileiras. Com a Copa do Mundo de 1974, a venda de receptores coloridos coloca definitivamente o Brasil no mundo da TV colorida. Com o Plano Real, em 1994, ocorreu a explosão das vendas de aparelhos de TV, agora com o con- trole remoto. O consumo televisivo das classes mais baixas foi ampliado. Só em 1996, foram vendidos oito milhões de televisores no Brasil.

\section{Referências}

ADORNO, Theodor. Indústria cultural e sociedade. Seleção de textos de José Mattos Brito de Almeida. São Paulo: Paz e Terra, 2002.

ANDRADE, Ana Luiza. Osman Lins: crítica e criação. São Paulo: Hucitec, 1987.

BENJAMIN, Walter. Magia e técnica, arte e política. São Paulo: Brasiliense, 1985.

CALVINO, Ítalo. Seis propostas para o próximo milênio. São Paulo: Companhia das Letras, 2015.

DEBORD, Guy. A sociedade do espetáculo. Rio de Janeiro: Contraponto, 1997.

GOMES DE MATOS, A. C. O outro lado da noite: filme noir. Rio de Janeiro: Rocco, 2001.

LINS, Osman. Casos especiais de Osman Lins. São Paulo: Summus, 1978.

. Guerra sem testemunhas. São Paulo: Ática, 1974.

1961.

O fiel e a pedra. São Paulo: Summus,

Os gestos. São Paulo: Melhoramentos, 1957.

Nove, novena. Rio de Janeiro: Guanabara, 1966.

Avalovara. São Paulo: Melhoramentos, 1973 .

. A rainha dos cárceres da Grécia. São Paulo: Melhoramentos, 1976.

Lisbela e o prisioneiro. São Paulo: Planeta, 1963.

NITRINI, Sandra. Poéticas em confronto: Nove, novena e o Novo Romance. São Paulo; Brasília: Hucitec, 1987. 
OLIVEIRA, Lucas Antunes. Labirinto sem minotauro: Roberto Bolaño e a narrativa policial na contemporaneidade. Tese (Doutorado em Teoria da Literatura) - Programa de Pós-Graduação em Letras, Universidade Federal de Pernambuco, Recife, 2016.

POE, Edgar Allan. Ficção completa, poesiae ensaios. Rio de Janeiro: Nova Aguilar, 1997.

TÁVOLA, Artur da. A ilha no espaço. Jornal O Globo, Caderno de Cultura, Rio de Janeiro, $1^{\circ}$ ago. 1975, p. 130.

TODOROV, Tzvetan. Introdução à literatura fantástica. São Paulo: Perspectiva, 1981.

VILA-MATAS, Enrique. Bartleby e companhia. São Paulo: Cosac Naify, 2004.

Suicídios exemplares. São Paulo: Cosac Naify, 2009. 